\title{
The correlations between Th1 and Th2 cytokines in human alveolar echinococcosis
}

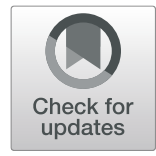

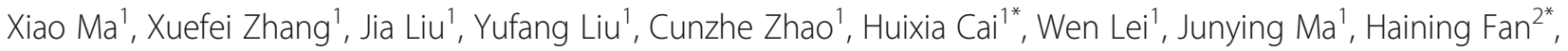 \\ Jianye Zhou ${ }^{3}$, Na Liu', Jingxiao Zhang', Yongshun Wang', Wei Wang ${ }^{1}$, Peizhen Zhan', Xiongying Zhang', \\ Qing Zhang ${ }^{1}$, Kemei Shi ${ }^{1}$ and Peiyun Liu ${ }^{1}$
}

\begin{abstract}
Background: Alveolar echinococcosis (AE) is a zoonotic parasitic disease caused by Echinococcus multilocularis larval tapeworm infections in humans that severely impairs the health of affected patients in the northern hemisphere.

Methods: The expression levels of 20 cytokines associated with AE infection were measured by enzyme-linked immunosorbent assay, and the correlations between these cytokines were analysed in the R programming language.

Results: Serum cytokine levels differed among individuals in both the AE patient and healthy control groups. The results of the correlations among the cytokines showed obvious differences between the two groups. In the AE patients group, Th1 and Th2 cytokines formed a more complicated network than that in the healthy control group.

Conclusions: The altered correlations between Th1 and Th2 cytokines may be closely associated with AE infection, which may provide a new explanation for the essential differences between AE patients and healthy individuals.
\end{abstract}

Keywords: Alveolar echinococcosis, Echinococcus multilocularis, Th1 cytokines, Th2 cytokines, Correlation analysis

\section{Background}

Alveolar echinococcosis (AE) is a severe parasitic disease caused by Echinococcus multilocularis larval tapeworm infection in humans that is fatal if left untreated $[1,2]$. The liver is the primary target of the disease and is affected in nearly $95 \%$ of cases; this disease can also spread and affect other organs, including the lungs, brain and bone $[1,3]$. AE causes severe damage or dysfunction of target organs $[4,5]$. This disease is restricted to the northern hemisphere, principally in rural areas of western, northern and eastern Europe; the highest disease prevalence is in central Asia, China and Kyrgyzstan [6, 7]. Epidemiological investigations have shown that

\footnotetext{
* Correspondence: huixia_1107@163.com; fanhaining@medmail.com.cn 'Qinghai Institute for Endemic Disease Prevention and Control, Xining 811602, Qinghai Province, China

${ }^{2}$ Qinghai University Affiliated Hospital, Xining 810000, Qinghai Province, China

Full list of author information is available at the end of the article
}

pastoral regions on the Tibetan Plateau appear to be high-risk areas for AE disease due to specific landscape features and husbandry practices. Specifically, a range of different wildlife hosts, especially small mammals, are involved in the transmission of E. multilocularis in a pastoral region of Qinghai province [5-7].

The World Health Organization (WHO) has listed echinococcosis as one of the 17 neglected diseases targeted for control or elimination by 2050 (http://whqlibdoc.who.int/ hq/2012/WHO_HTM_NTD_2012.1_eng.pdf). To date, surgery is the only potentially curative option for the treatment of $\mathrm{AE}$; however, $\mathrm{AE}$ recurrence after hepatectomy is high, and many patients present with inoperable disease [8]. Recently, immunotherapy has been used to complement anti-infective drug approaches, and this approach was suggested to be highly effective in treating echinococcosis; however, there is no accepted immunotherapy

(c) The Author(s). 2020 Open Access This article is licensed under a Creative Commons Attribution 4.0 International License, which permits use, sharing, adaptation, distribution and reproduction in any medium or format, as long as you give appropriate credit to the original author(s) and the source, provide a link to the Creative Commons licence, and indicate if changes were made. The images or other third party material in this article are included in the article's Creative Commons licence, unless indicated otherwise in a credit line to the material. If material is not included in the article's Creative Commons licence and your intended use is not permitted by statutory regulation or exceeds the permitted use, you will need to obtain permission directly from the copyright holder. To view a copy of this licence, visit http://creativecommons.org/licenses/by/4.0/. The Creative Commons Public Domain Dedication waiver (http://creativecommons.org/publicdomain/zero/1.0/) applies to the data made available in this article, unless otherwise stated in a credit line to the data. 
against $\mathrm{AE}$ infection due to the complicated interactions between the parasites and host immunity.

The type of immune response impacts disease development, and T helper (Th) cells can selectively differentiate into the Th1 or Th2 subtype in response to an $E$. multilocularis antigen. A Th1/Th2 imbalance has been suggested to play an important role in controlling the immunological response to $\mathrm{AE}$ infection $[9,10]$. AE patients with Th1-oriented immunity are more likely to harbour fewer parasites or even aborted parasites, whereas AE patients with Th2-oriented immunity are more likely to develop chronic AE [11]. In mice, the Th1 response was shown to dominate at the early stage of $\mathrm{AE}$, and the immune response gradually shifted towards a Th2-dominated response at the late stage of AE to prevent Th1-mediated damage $[11,12]$. The imbalance between Th1-type cytokines and Th2-type cytokines in AE is not completely understood due to the limited number of studies, regional differences and complex interactions between parasites and host immunological and genetic factors $[9,12]$.

In this study, 20 cytokines, including Th1 and Th2 cytokines, were selected according to the related literature [13-15]. The expression levels of these cytokines were compared and analysed by bioinformatics and statistical analysis methods to explore the correlations among Th1- and Th2-type cytokines in AE patients and healthy controls from Qinghai Province in China.

\section{Methods}

\section{Study groups and sample collection}

The participants consisted of $45 \mathrm{AE}$ patients $(29 \mathrm{fe}-$ males/16 males) and 45 healthy people (27 females/18 males). The mean age of the AE patients was 38 years (range, 21-52 years), and the mean age of the healthy controls was 39 years (range, 26-53 years). All the recruited participants were Tibetan and lived in the Guoluo Tibetan Autonomous Prefecture of Qinghai Province, and 91\% were herdsmen. The diagnosis of $\mathrm{AE}$ was according to the People's Republic of China Health Industry Standard-Diagnostic Criteria for Hydatid Disease (WS257-2006) by a professional doctor. The classification of $\mathrm{AE}$ patients in different clinical stages of $\mathrm{AE}$ was accomplished according to the World Health Organization- (WHO-) PNM (P: Hepatic localization of the metacestode; N: Extrahepatic involvement of neighbouring organs; and M: Presence or absence of distant metastases), detailed in Table 1 . No patients had received any anti-inflammatory drugs or anti-parasitic drugs, and none had undergone a curative hepatectomy or a liver transplantation before the study. All healthy controls showed normal abdominopelvic cavity images as detected by B-mode ultrasound. Written consent was obtained from all participants, and this study was
Table 1 The classification of AE patients

\begin{tabular}{|c|c|c|c|}
\hline \multicolumn{3}{|l|}{ Classification } & \multirow{2}{*}{$\frac{\text { Percentage (\%) }}{27(60 \%)}$} \\
\hline Lesion numbers & & Single (\%) & \\
\hline & & Double(\%) & $14(31.1 \%)$ \\
\hline & & Multiple (\%) & $4(8.8 \%)$ \\
\hline \multirow[t]{6}{*}{ PNM classification } & $P$ & P1 (\%) & $10(22.2 \%)$ \\
\hline & & P2 (\%) & $15(33.3 \%)$ \\
\hline & & P3 (\%) & $18(40 \%)$ \\
\hline & & P4 (\%) & $2(4.4 \%)$ \\
\hline & $\mathrm{N}$ & 0 & not detected \\
\hline & M & & undetected \\
\hline \multirow{3}{*}{$\begin{array}{l}\text { Lesion classification (67 } \\
\text { lesions in } 45 \text { patients) }\end{array}$} & & Infiltrating type (\%) & 49 (73.1\%) \\
\hline & & Calcification type (\%) & $5(7.5 \%)$ \\
\hline & & Liquefied cavity type (\%) & 13 (19.4\%) \\
\hline
\end{tabular}

Note: No adjacent organs or tissues were found to be infected in all patients: $\mathrm{M}$ classification was not provided due to poor medical conditions and remote areas

approved by the Ethics Committee of Qinghai Institute of Endemic Disease Control and Prevention.

Five millilitres of peripheral venous blood was harvested from each participant after an 8- to 12-h fast under strict precautions in sterile tubes containing EDTA anticoagulation, and $1 \mathrm{~mL}$ of serum was immediately separated from the blood and preserved at $-80^{\circ} \mathrm{C}$ for the measurement of cytokines.

\section{Serum analysis}

The serum levels of 20 cytokines in $\mathrm{AE}$ patients and healthy controls were measured by an enzyme-linked immunosorbent assay (ELISA) kit (Thermo Scientific) according to the manufacturer's protocols. All samples were measured three times for each cytokine, and the mean value was taken for analysis. The 20 analysed cytokines are listed in Table 2.

\section{Literature review}

We searched related studies in the PubMed database using the keywords "cytokine" and "alveolar echinococcosis" to explore data on cytokine expression in previous studies associated with AE from 1990 to 2019. After a literature review, a total of 56 studies were identified, 16 of which reported cytokine levels in human AE.

Table 2 The Th1 and Th2 cytokines analysed in the study

\begin{tabular}{ll}
\hline Cytokine type & Specific cytokines \\
\hline Th1 cytokines & $\mathrm{IL}-8, \mathrm{IL}-2, \mathrm{IL}-12, \mathrm{IL}-1 \beta, \mathrm{IFN}-\mathrm{\gamma}$-inducible protein \\
& $10(\mathrm{IP}-10), \mathrm{MIP}-1 \beta, \mathrm{MCP}-1 \mathrm{a}$, and IFN- $\gamma$. \\
Th2 cytokines & $\mathrm{IL}-4, \mathrm{LL}-5, \mathrm{LL}-6, \mathrm{IL}-13, \mathrm{IL}-18, \mathrm{~B}, \mathrm{RO}-\mathrm{a}$, and eotaxin. \\
Both Th1 and & $\begin{array}{l}\text { Stromal cell-derived factor (SDF-1a),TNF-a, } \\
\text { Th2 cytokines }\end{array}$ \\
& $\begin{array}{l}\text { GM-CSF, MIP-1a, and regulated on activation, } \\
\text { normal T cell expressed and secreted (RANTES). }\end{array}$ \\
\hline
\end{tabular}




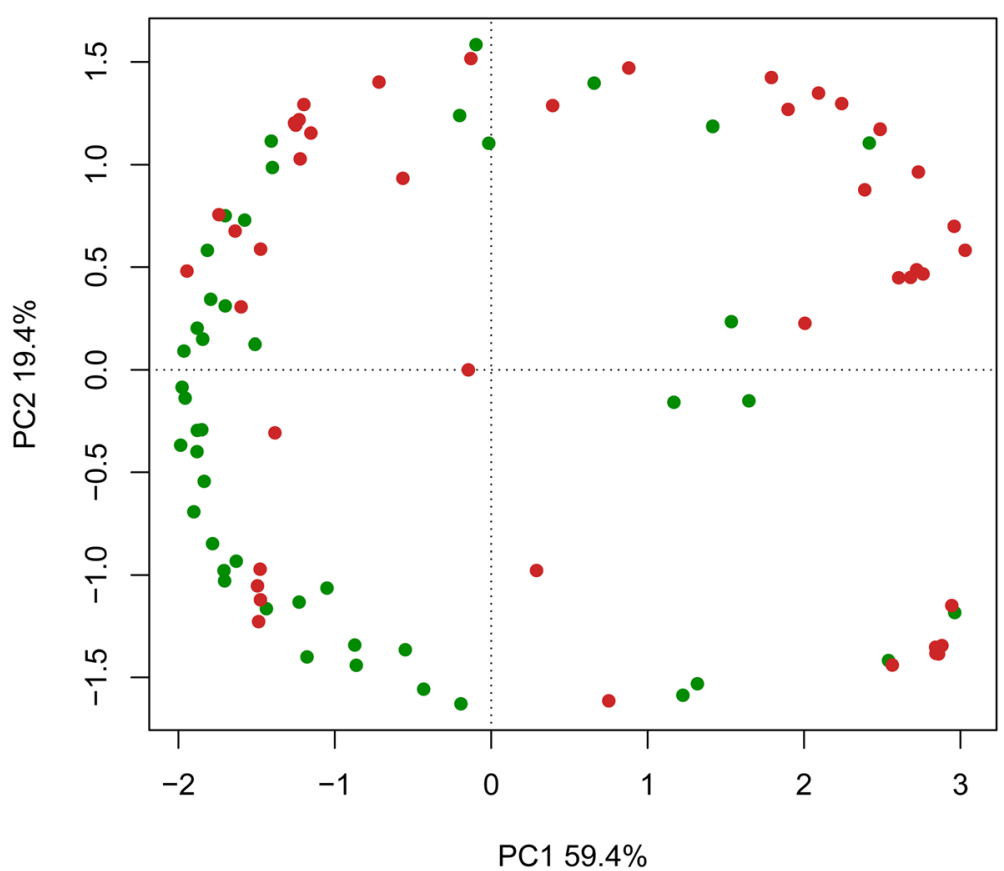

Fig. 1 PCA of AE patients (orange) and healthy controls (green) based on the Bray-Curtis distance. The percentages of variance explained by PC1 and PC2 are 59.4 and $19.4 \%$, respectively

\section{Statistical methods}

The relationships between the AE patient group and the healthy group were analysed by a principal component analysis (PCA) performed based on the Bray-Curtis distance matrix across the samples using the vegan package in $\mathrm{R}$ (version 3.4.4). Student's t-test was performed to compare $\mathrm{PC} 1 / \mathrm{PC} 2$ between groups using the stats package in R. Spearman's correlations between cytokines were calculated using the Hmisc package in $\mathrm{R}$. The correlation networks between cytokines were constructed using the GeneNet package in $\mathrm{R}$ and were further visualized using Cytoscape 3.4.0 [16].

\section{Results}

\section{Cytokine analysis}

The expression levels of 20 cytokines were compared between the AE patient group and the healthy control group, while the ELISA results showed that cytokine expression levels differed among individuals in both the $\mathrm{AE}$ patient and healthy control groups.

\section{PCA of AE patients and healthy controls}

The PCA showed that most samples in the AE patient group had obviously different cytokine compositions

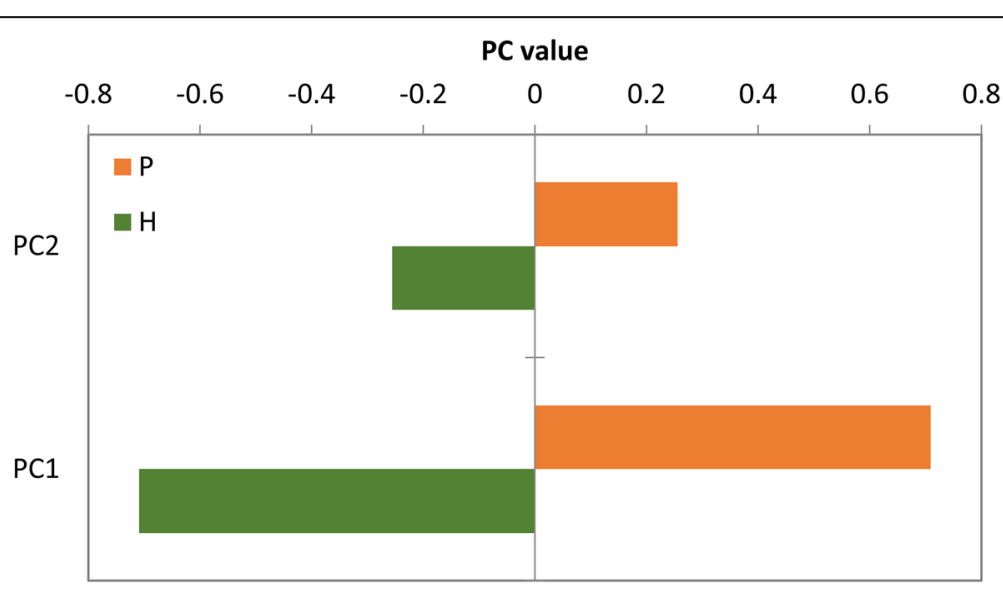

Fig. 2 Comparison of PC1 and PC2 values between AE patients and healthy controls 

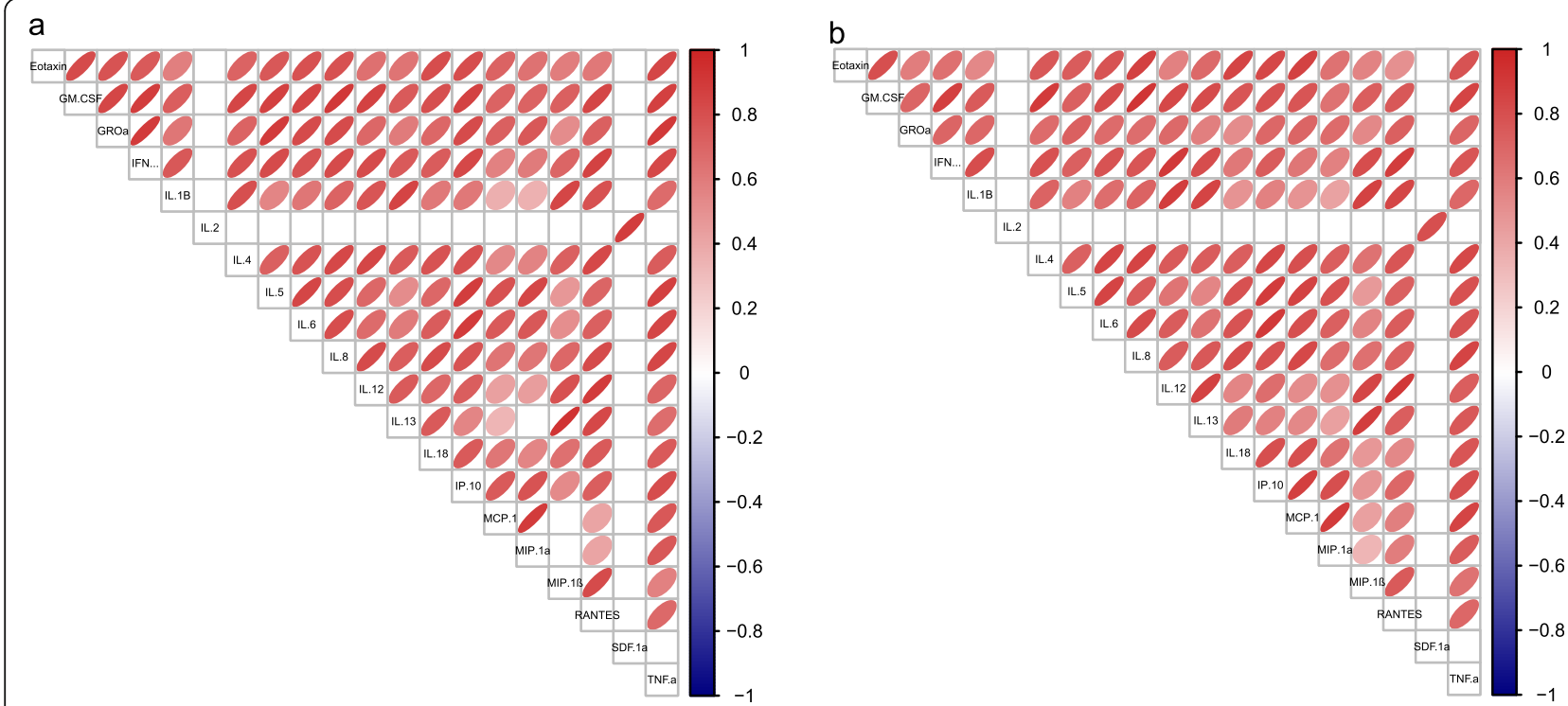

Fig. 3 Spearman's correlations among cytokines in the healthy controls (a) and the AE patients (b)

than those in the healthy control group, while a few samples showed similarity (Fig. 1). The differences in cytokine composition between the two groups were further analysed by comparing their $\mathrm{PC} 1$ and $\mathrm{PC} 2$ values (Fig. 2); these values were significantly different between the two groups $(P<0.001)$.

\section{Correlations between the cytokines}

The correlations among some cytokines were obviously different between the two groups. In the healthy control group, there was no correlation between MIP$1 \alpha$ and IL-13 or among MCP-1, MCP- $1 \alpha$ and MIP- $1 \beta$
(Fig. 3a). These cytokines had weak correlations in the AE patient group (Fig. 3b).

A partial correlation network analysis of the cytokines confirmed the presence of more complex cytokine interactions in the $\mathrm{AE}$ patient group than in the healthy control group (Fig. 4a and b). In the healthy controls, the correlations were simple, and just a few of cytokines showed correlations between each other: IL-8(Th1) $\operatorname{Eotaxin}(\mathrm{Th} 2) \_I L-4(\mathrm{Th} 2) ;$ GM-CSF (Th2)_IL-5(Th2)_IL13(Th2); (IFN)- $\gamma$ (Th1)_(GRO)- $\alpha$ (Th2)_MCP-1 $\alpha($ Th1); and SDF $1 \alpha$ (Th2)_IL-2(Th1)(Fig. 4a). In the AE patients group, Th1 and Th2 cytokines formed a more complicated a
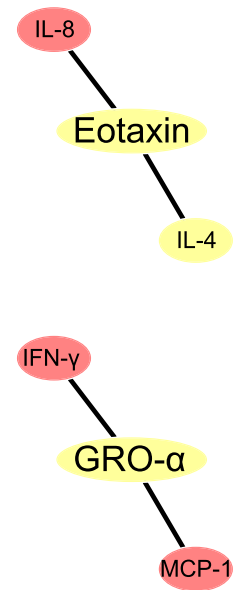

b

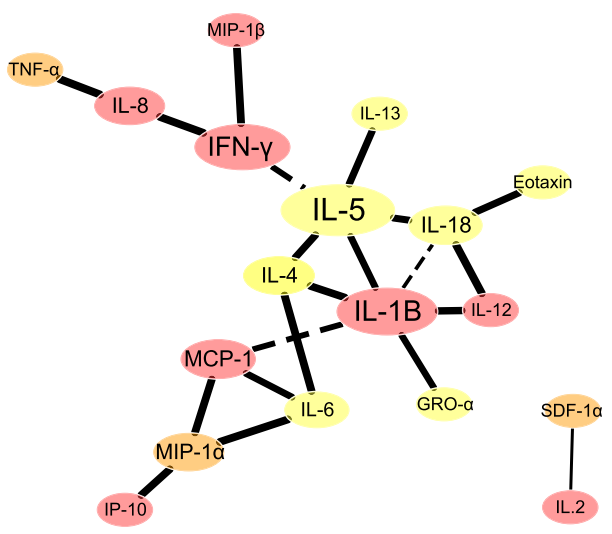

Fig. 4 Partial correlation networks among cytokines in the healthy controls (a) and AE patients (b). Note: The colour of the node indicates the origin of the cytokine: red, Th1; yellow, Th2; and orange, both Th1 and Th2. The size of the node indicates the betweenness centrality; a node with increased betweenness centrality has increased control over the network. The solid and dotted lines indicate positive and negative relationships, respectively 
Table 3 The expression levels of cytokines in E. multilocularis-infected humans

\begin{tabular}{|c|c|c|c|c|c|}
\hline Cytokine type & Cytokine & Experimental type & Methods and results & Specimens & Citation \\
\hline$\overline{\mathrm{TH} 2}$ & IL-10 & in vitro & $\begin{array}{l}\text { IL-10 levels in CD8+ lymphocytes from } p \\
\text { rogressive AE patients }(N=12) \text { were } \\
\text { definitely increased after in vitro culture } \\
\text { with crude } E \text {. multilocularis antigen using } \\
\text { a protocol for intracellular staining of } \\
\text { cytokines followed by fluorescence- } \\
\text { activated cell sorting (FACS) analysis. }\end{array}$ & $\begin{array}{l}\text { CD8+ lymphocytes } \\
\text { cultured in vitro }\end{array}$ & Kilwinski et al. [17] \\
\hline $\mathrm{TH} 2$ & $\mathbb{I L}-10$ & in vitro & $\begin{array}{l}\text { Peripheral blood mononuclear cells } \\
\text { (PBMCs) isolated from progressive AE } \\
\text { patients }(N=9) \text { secreted significantly } \\
\text { higher amounts of IL-10 than those } \\
\text { isolated from abortive AE patients } \\
(N=3) \text {; IL-10 was detected by using } \\
\text { real-time PCR. }\end{array}$ & $\begin{array}{l}\text { PBMCs cultured with } \\
\text { Emf stimulation. }\end{array}$ & Godot et al. [18] \\
\hline $\mathrm{TH} 2$ & $\mid \mathrm{L}-10$ & clinical test & $\begin{array}{l}\text { Serum IL-10 levels were significantly } \\
\text { higher in AE patients }(N=40) \text { than } \\
\text { in healthy controls }(N=20) \text {, with a } \\
\text { tendency to higher concentrations } \\
\text { in progressive cases; IL-10 was } \\
\text { determined by ELISA. }\end{array}$ & Serum & Wellinghausen et al. [19] \\
\hline $\mathrm{TH} 2$ & $\| \mathrm{L}-5$ & in vitro & $\begin{array}{l}\text { IL-5 production was particularly } \\
\text { increased in PBMCs from patients } \\
\text { with advanced AE ( } n=14) \text { after } \\
\text { stimulation with crude E. multilocularis } \\
\text { antigenic preparations; IL-5 was } \\
\text { detected by RT-PCR. }\end{array}$ & PBMCs & Jenne et al. [20] \\
\hline $\mathrm{TH} 2$ & $\begin{array}{l}\text { IL-5, } \\
\text { IL-6, IL-10 }\end{array}$ & clinical test & $\begin{array}{l}\text { Plasma concentration levels of IL-5, } \\
\text { IL-6, and IL- } 10 \text { were slightly increased } \\
\text { in consecutive AE patients ( } N=28 \text {, } \\
\text { and IL- } 23 \text { concentration levels were } \\
\text { significantly higher in AE patients; } \\
\text { the cytokines were detected by ELISA. }\end{array}$ & Plasma & Tuxun et al. [21] \\
\hline $\mathrm{TH} 2$ & TGF- $\beta$ & clinical test & $\begin{array}{l}\text { Serum TGF- } \beta \text { levels were high, and } \\
\text { TGF- } \beta \text { was expressed by most of } \\
\text { the infiltrating lymphocytes in } \\
\text { progressive AE patients }(N=18) \text { by } \\
\text { means oOf immunochemical staining } \\
\text { of liver sections. }\end{array}$ & Surgical biopsy specimens & Zhang et al. [22] \\
\hline $\mathrm{TH} 2$ & TGF- $\beta$ & in vitro & $\begin{array}{l}\text { Higher levels of TGF- } \beta \text { were observed } \\
\text { in PBMC supernatant after exposure } \\
\text { to Em vesicular fluid (VF) than that } \\
\text { from healthy blood donors; TGF- } \beta \\
\text { was detected using flow cytometry } \\
\text { and ELISA, respectively. }\end{array}$ & PBMCs supernatant & Bellanger et al. [23] \\
\hline $\mathrm{TH} 2$ & TGF- $\beta$ & in vitro & $\begin{array}{l}\text { A significant increase in TGF- } \beta \\
\text { production was induced in PBMCs } \\
\text { from healthy blood donors after } \\
\text { exposure to Em-VF and Toll-like } \\
\text { receptor agonists by using Multiplex } \\
\text { Luminex }^{\oplus} \text { bead technology. }\end{array}$ & $\begin{array}{l}\text { PBMCs exposure to Em-VF } \\
\text { and Toll-like receptor } \\
\text { agonists }\end{array}$ & Bellanger et al. [24] \\
\hline $\mathrm{TH} 1$ & IL-8, MCP-1 & in vitro & $\begin{array}{l}\text { Peripheral blood cells isolated from } \\
\text { AE patients }(N=30) \text { induced significant } \\
\mathrm{IL}-8 \text { and } \mathrm{MCP}-1 \text { production when } \\
\text { cultured with viable proliferating } \\
\text { E. multilocularis metacestode }(E m) \\
\text { vesicles; IL-8 and MCP-1 were detected } \\
\text { by ELISA. }\end{array}$ & $\begin{array}{l}\text { PBMCs cultured with Em } \\
\text { vesicles }\end{array}$ & Dreweck et al. [25] \\
\hline TH1 & $\mathrm{IFN}-\gamma$ & clinical test & $\begin{array}{l}\text { The mean concentration of IFN- }- \text { in } \\
\text { serum from AE patients }(N=23) \text { was } \\
\text { higher than that in control group; } \\
\text { IFN- } \gamma \text { was detected by double antibody } \\
\text { sandwich. }\end{array}$ & Serum & Shi et al. [26] \\
\hline
\end{tabular}


Table 3 The expression levels of cytokines in E. multilocularis-infected humans (Continued)

\begin{tabular}{|c|c|c|c|c|c|}
\hline Cytokine type & Cytokine & Experimental type & Methods and results & Specimens & Citation \\
\hline TH9 & IL-9 & in vitro & $\begin{array}{l}\text { Th9-related cytokine IL-9 mRNA levels } \\
\text { were both elevated in PBMCs and in } \\
\text { hepatic lesion and paralesion tissues } \\
\text { in AE patients }(N=14) ; \mathrm{IL}-9 \text { mRNA } \\
\text { levels were detected by real-time PCR. }\end{array}$ & PBMCs and liver tissues & Tuxun et al. [10] \\
\hline Th17 & IL-17 & clinical test & $\begin{array}{l}\text { The plasma levels of the } \\
\text { proinflammatory cytokine IL-17B } \\
\text { and its soluble receptor sIL-17RB } \\
\text { were significantly elevated in AE } \\
\text { patients }(N=93) \text {; IL-17B was detected } \\
\text { by ELISA. }\end{array}$ & Plasma & Lechner et al. [27] \\
\hline Th17 & IL-23 & in vitro & $\begin{array}{l}\text { IL-17A and IL-23 mRNAs levels were } \\
\text { significantly elevated in the PBMCs } \\
\text { isolated from AE patients }(N=30) \text {, } \\
\text { and the levels were detected by } \\
\text { real-time PCR. }\end{array}$ & PBMCs & Tuxun, et al. [28] \\
\hline $\mathrm{TH} 2$ and $\mathrm{TH} 1$ & $\begin{array}{l}\text { IL-10, } \\
\text { IFN-Y }\end{array}$ & in vitro & $\begin{array}{l}\text { Emf-stimulated mononuclear cells } \\
\text { from the central part of the } \\
\text { granulomatous lesions secreted more } \\
\text { IL-10 (TH2) and less IFN- } \gamma(T H 1) \text { than } \\
\text { cells from the periphery of the } \\
\text { granuloma in progressive AE patients } \\
(\mathrm{N}=1) \text {; the cytokines were detected } \\
\text { by ELISA. }\end{array}$ & $\begin{array}{l}\text { Emf-stimulated } \\
\text { mononuclear cells }\end{array}$ & Harraga et al. [29] \\
\hline $\mathrm{TH} 2$ and $\mathrm{TH} 1$ & $\begin{array}{l}\text { IL-31, } \\
\text { IL-33, } \\
\text { IL-27, } \\
\text { SDF-1, } \\
\text { eotaxin }\end{array}$ & in vitro & $\begin{array}{l}\text { The spontaneous cellular release } \\
\text { of TH2-type cytokines IL-31 and } \\
\text { IL-33 was clearly depressed in } \\
\text { patients with cured, stable, and } \\
\text { progressive AE }(N=57) \text {, whereas } \\
\text { the levels of the TH1-type cytokine } \\
\text { IL-27, anti-inflammatory cytokine } \\
\text { SDF-1, and eotaxin increased with } \\
\text { disease progression; the cytokines } \\
\text { were detected by ELISA. }\end{array}$ & PBMC culture supernatants & Huang et al. [30] \\
\hline Both $\mathrm{TH} 1$ and $\mathrm{TH} 2$ & $\begin{array}{l}\text { MIP-1a, } \\
\text { MIP-1 } \beta \text {, } \\
\text { RANTES, } \\
\text { GRO- } a\end{array}$ & in vitro & $\begin{array}{l}\text { The production of CC and CXC } \\
\text { chemokines, which associate with } \\
\text { inflammation (MIP-1a/CCL3, MIP- } \\
1 \beta / C C L 4, \text { RANTES/CCL5 and GRO- } \alpha \text { / } \\
\text { CXCL1) was constitutively higher in } \\
\text { PBMCs when cultured with E. } \\
\text { multilocularis antigen in patients } \\
\text { with progressive, stable or cured } \\
\text { AE }(N=75) \text { than in controls; the } \\
\text { chemokines were detected by ELISA. }\end{array}$ & $\begin{array}{l}\text { PBMCs cultured with } \\
\text { Em antigen }\end{array}$ & Kocherscheidt et al. [31] \\
\hline
\end{tabular}

network, and more Th1 (MCP-1 $\alpha$, IL-1 $\beta$, IFN- $\gamma$, and IL-8) and Th2 cytokines (IL-5, IL-4, IL-18) showed close correlations (Fig. 4b).

\section{Discussion}

In the present study, the expression levels of 20 cytokines were detected to determine some differences between $\mathrm{AE}$ patients and healthy controls, while the results were confusing, as they differed among individuals in both the AE patient and healthy control groups. We then summarized the related literature about cytokines associated with human $\mathrm{AE}$, and the results showed that the kinds of 'different cytokines' were not always consistent (Table 3), indicating that it is seemingly difficult to discover biomarkers for human $\mathrm{AE}$ at the cytokine expression level due to the complex factors in $\mathrm{AE}$ affecting the process.

To further understand the differences in cytokines between the two groups, we used omics methods, and the results of PCA analysis indicated that cytokine compositions were obviously different between the two groups and that the networks of cytokine correlations were more complicated in the AE patient group than that in the healthy control group. According to the correlation network results, the weak or strong correlations between Th1 and Th2 cytokines could explain the essential differences between the $\mathrm{AE}$ patients and the healthy controls. E. multilocularis metacestodes may modulate the secretion of Th1 and Th2 cytokines by Th lymphocytes 
in $\mathrm{AE}$ patients [32], and the cytokine orientation depends on the host immune response induced by $E$. multilocularis antigens [33]. Th1 cell activation induces considerable protective immunity, which involves the initiating cytokines IFN- $\alpha$ and IL-12 and the effector cytokines IFN- $\gamma$ and tumour necrosis factor (TNF)- $\alpha$, to defend against intracellular parasitic infections [34, 35]. Th2 cytokines allow parasites to proliferate at low rates by producing high levels of IL-4, IL-5 and IL-10 [13, 14]. E. multilocularis antigenic preparations have been reported to induce increased IL-5 production due to the activation of $\mathrm{CD} 4^{+} \mathrm{T}$ lymphocytes in patients with progressive $\mathrm{AE}$ [20]. In the present study, the correlation between the Th2-type cytokine IL-5 and the Th1-type cytokines IFN- $\gamma$ and IL-1 $\beta$ in AE patients may be associated with the enhanced immunological response induced by parasite infection, which indicates that an inflammatory reaction is induced in $\mathrm{AE}$ patients. In addition, the Th2 cytokines GRO- $\alpha$ and eotaxin were well controlled by the Th1 cytokines MCP-1, IFN- $\gamma$ and IL- 8 in the healthy control group, whereas GRO- $\alpha$ and eotaxin levels were poorly controlled by Th1 cytokines in the $\mathrm{AE}$ patient group, confirming the presence of an inflammatory response in $\mathrm{AE}$ patients. The altered correlations among the cytokines may explain the essential differences between the $\mathrm{AE}$ patients and the healthy controls.

Furthermore, this parasite can secrete proteins to regulate the host immune response and survive in humans for long periods of time, and different secreted protein profiles at different stages of $\mathrm{AE}$ progression may explain the complex interactions between the parasite and the host [36]. A proteomic analysis of cyst vesicular fluids in $\mathrm{AE}$ patients contributed to the identification of potential molecular markers for diagnostic and follow-up tools, but the mechanism underlying the interplay between secreted proteins and cytokines requires further exploration.

\section{Conclusions}

The correlations between Th1 and Th2 cytokines were simple in the healthy control group but complex in the $\mathrm{AE}$ patient group. Th1 cytokines, such as IFN- $\gamma, \mathrm{IL}-1 \beta$ and MCP-1, had high betweenness centrality in $\mathrm{AE}$ patients, whereas Th2 cytokines, such as GRO- $\alpha$, eotaxin and IL-5, had high betweenness centrality in the healthy control group. These findings may provide a new point of view to study the significant difference between $\mathrm{AE}$ patients and healthy individuals. However, more studies in the future will be required to clarify the "biomarkers", such as studies including "clinically relevant populations" (such as liver non-parasitic benign cysts, liver abscesses, and mesenteric cysts) as controls, with prospective follow-up and involving large sample sizes.

\section{Abbreviations}

AE: Alveolar echinococcosis; ELISA: Enzyme-linked immunosorbent assay; GM-CSF: Granulocyte-macrophage colony-stimulating factor; GRO-a: Growthregulated oncogene-alpha; IP-10: Interferon-gamma (IFN-ץ)-inducible protein 10; IL: Interleukin; MIP-1a: Macrophage inflammatory protein-1a; MIP1B: Macrophage inflammatory protein-1 $\beta$; MCP-1a: Monocyte chemoattractant protein; RANTES: Regulated on activation, normal T cell expressed and secreted; PCA: Principal component analysis; SDF-1a: Stromal cell-derived factor-1a; Th cells: T helper cells; TNF-a: Tumour necrosis factor a; WHO: World Health Organization

\section{Acknowledgements \\ We are extremely grateful to Dr. Haining Fan for the advice on the study design.}

\section{Authors' contributions}

$X \mathrm{M}, \mathrm{HX} \mathrm{C}, \mathrm{HN} F$ and JY Z conceived of and designed the study, and interpreted the results. $X M, X F Z$ and $J L$ carried out the screening and epidemiological data collection in epidemic areas. YF $L, C Z Z, W L$, and JY M conducted clinical assessments. N L, JX Z and YS W carried out the blood collection, serum separation and data collection of part epidemic areas. W W and PZ Z performed the experiments of Elisa. X M, XY Z and Q Z performed the statistical analyses and wrote the manuscript. KM S and PY $L$ did the work of literature review. All authors read and approved the final manuscript.

\section{Funding}

This study was supported by the Science and Technology Major Project of Qinghai Province (No. 2016-SF-A5)

Availability of data and materials

Data supporting the conclusions are included within the article.

Ethics approval and consent to participate

The study was approved by the Ethics Committee of Qinghai Institute of Endemic Disease Control and Prevention, and all participants signed informed consent forms.

Consent for publication

Not applicable.

Competing interests

The authors declare that they have no competing interests.

\section{Author details}

'Qinghai Institute for Endemic Disease Prevention and Control, Xining 811602, Qinghai Province, China. ${ }^{2}$ Qinghai University Affiliated Hospital, Xining 810000, Qinghai Province, China. ${ }^{3}$ Biomedical Research Center, Northwest Minzu University, Lanzhou 730000, Gansu Province, China.

Received: 10 January 2020 Accepted: 1 June 2020

Published online: 15 June 2020

\section{References}

1. Gencheva DG, Menchev DN, Penchev DK, Tokmakova MP. An incidental finding of heart echinococcosis in a patient with infective endocarditis: a case report. Folia Med (Plovdiv). 2017;59:110-3.

2. Kern P, Silva AMD, Akhan O, Mullhaupt B, Vizcaychipi KA, Budke C, et al. The echinococcoses: diagnosis, clinical management and burden of disease. Adv Parasitol. 2017;96:259-369

3. Tamarozzi F, Mariconti M, Neumayr A, Brunetti E. The intermediate host immune response in cystic echinococcosis. Parasite Immunol. 2016;38: 170-81.

4. Wen H, Vuitton L, Tuxun T, Li J, Vuitton DA, Zhang W, et al. Echinococcosis: advances in the 21st century. Clin Microbiol Rev. 2019;32:e00075-18.

5. Feng X, Qi X, Yang L, Duan X, Fang B, Gongsang Q, et al. Human cystic and alveolar echinococcosis in the Tibet autonomous region (TAR), China. J Helminthol. 2015;89:671-9.

6. Baumann S, Shi R, Liu W, Bao H, Schmidberger J, Kratzer W, et al. Worldwide literature on epidemiology of human alveolar echinococcosis: a systematic review of research published in the twenty-first century. Infection. 2019;47: $703-27$. 
7. Li T, Chen X, Zhen R, Qiu J, Qiu D, Xiao N, et al. Widespread co-endemicity of human cystic and alveolar echinococcosis on the eastern Tibetan plateau, Northwest Sichuan/Southeast Qinghai. China Acta Trop. 2010;113: 248-56.

8. Nunnari G, Pinzone MR, Gruttadauria S, Celesia BM, Madeddu G, Malaguarnera G, et al. Hepatic echinococcosis: clinical and therapeutic aspects. World J Gastroenterol. 2012;18:1448-58.

9. Wang J, Jebbawi F, Bellanger AP, Beldi G, Millon L, Gottstein B. Immunotherapy of alveolar echinococcosis via PD-1/PD-L1 immune checkpoint blockade in mice. Parasite Immunol. 2018;40:e12596.

10. Tuxun T, Apaer S, Ma HZ, Zhang H, Aierken A, Lin RY, et al. The potential role of Th9 cell related cytokine and transcription factors in patients with hepatic alveolar echinococcosis. J Immunol Res. 2015;2015:895416.

11. Wang J, Cardoso R, Marreros N, Muller N, Lundstrom-Stadelmann B, Siffert $\mathrm{M}$, et al. Foxp $3^{+} \mathrm{T}$ regulatory cells as a potential target for immunotherapy against primary infection with echinococcus multilocularis eggs. Infect Immun. 2018;86:e00542-18.

12. Mejri N, Hemphill A, Gottstein B. Triggering and modulation of the hostparasite interplay by Echinococcus multilocularis: a review. Parasitology. 2010; 137:557-68.

13. Borish LC, Steinke JW. 2. Cytokines and chemokines. J Allergy Clin Immunol. 2003;111:S460-75.

14. Wang J, Gottstein B. Immunoregulation in larval Echinococcus multilocularis infection. Parasite Immunol. 2016;38:182-92.

15. Pakala T, Molina M, Wu GY. Hepatic echinococcal cysts: a review. J Clin Transl Hepatol. 2016;4:39-46.

16. Killcoyne S, Carter GW, Smith J, Boyle J. Cytoscape: a community-based framework for network modeling. Methods Mol Biol. 2009;563:219-39.

17. Kilwinski J, Jenne L, Jellen-Ritter A, Radloff P, Flick W, Kern P. T lymphocyte cytokine profile at a single cell level in alveolar echinococcosis. Cytokine. 1999;11:373-81.

18. Godot V, Harraga S, Beurton I, Deschaseaux M, Sarciron E, Gottstein B, et al. Resistance/susceptibility to Echinococcus multilocularis infection and cytokine profile in humans. I. Comparison of patients with progressive and abortive lesions. Clin Exp Immunol. 2000;121:484-90.

19. Wellinghausen N, Gebert P, Kern P. Interleukin (IL)-4, IL-10 and IL-12 profile in serum of patients with alveolar echinococcosis. Acta Trop. 1999;73:165-74.

20. Jenne L, Kilwinski J, Scheffold W, Kern P. IL-5 expressed by CD4+ lymphocytes from Echinococcus multilocularis-infected patients. Clin Exp Immunol. 1997;109:90-7.

21. Tuxun T, Ma HZ, Apaer S, Zhang H, Aierken A, Li YP, et al. Expression of tolllike receptors 2 and 4 and related cytokines in patients with hepatic cystic and alveolar echinococcosis. Mediat Inflamm. 2015;2015:632760.

22. Zhang S, Hue S, Sene D, Penfornis A, Bresson-Hadni S, Kantelip B, et al. Expression of major histocompatibility complex class I chain-related molecule a, NKG2D, and transforming growth factor-beta in the liver of humans with alveolar echinococcosis: new actors in the tolerance to parasites? J Infect Dis. 2008;197:1341-9.

23. Bellanger AP, Mougey V, Pallandre JR, Gbaguidi-Haore H, Godet Y, Millon L. Echinococcus multilocularis vesicular fluid inhibits activation and proliferation of natural killer cells. Folia Parasitol (Praha). 2017;64:2017 029.

24. Bellanger AP, Pallandre JR, Gbaguidi-Haore H, Knapp J, Malezieux N, Lignon T, et al. Investigating the impact of Echinococcus multilocularis vesicular fluid on human cells from healthy blood donors. J Immunol Methods. 2015;417: 52-9.

25. Dreweck CM, Soboslay PT, Schulz-Key H, Gottstein B, Kern P. Cytokine and chemokine secretion by human peripheral blood cells in response to viable Echinococcus multilocularis metacestode vesicles. Parasite Immunol. 1999;21: 433-8.

26. Shi DZ, Li FR, Bartholomot B, Vuitton DA, Craig PS. Serum sIL-2R, TNF-alpha and IFN-gamma in alveolar echinococcosis. World J Gastroenterol. 2004;10: 3674-6.

27. Lechner CJ, Gruner B, Huang X, Hoffmann WH, Kern P, Soboslay PT. Parasitespecific IL-17-type cytokine responses and soluble IL-17 receptor levels in alveolar echinococcosis patients. Clin Dev Immunol. 2012;2012:735342.

28. Tuxun T, Apaer S, Ma HZ, Zhao JM, Lin RY, Aji T, et al. Plasma IL-23 and IL-5 as surrogate markers of lesion metabolic activity in patients with hepatic alveolar echinococcosis. Sci Rep. 2018;8:4417.

29. Harraga S, Godot V, Bresson-Hadni S, Mantion G, Vuitton DA. Profile of cytokine production within the periparasitic granuloma in human alveolar echinococcosis. Acta Trop. 2003;85:231-6.
30. Huang X, Gruner B, Lechner CJ, Kern P, Soboslay PT. Distinctive cytokine, chemokine, and antibody responses in Echinococcus multilocularis-infected patients with cured, stable, or progressive disease. Med Microbiol Immunol. 2014:203:185-93.

31. Kocherscheidt L, Flakowski AK, Gruner B, Hamm DM, Dietz K, Kern P, et al. Echinococcus multilocularis: inflammatory and regulatory chemokine responses in patients with progressive, stable and cured alveolar echinococcosis. Exp Parasitol. 2008;1 19:467-74.

32. Hubner MP, Manfras BJ, Margos MC, Eiffler D, Hoffmann WH, Schulz-Key H, et al. Echinococcus multilocularis metacestodes modulate cellular cytokine and chemokine release by peripheral blood mononuclear cells in alveolar echinococcosis patients. Clin Exp Immunol. 2006;145:243-51.

33. Siracusano A, Delunardo F, Teggi A, Elena O. Cystic Echinococcosis: aspects of immune response, Immunopathogenesis and immune evasion from the human host. Endocr Metab Immune Disord Drug Targets. 2012;12:16-23.

34. Liance M, Ricard-Blum S, Emery I, Houin R, Vuitton DA. Echinococcus multilocularis infection in mice: in vivo treatment with a low dose of IFNgamma decreases metacestode growth and liver fibrogenesis. Parasite. 1998;5:231-7.

35. Emery I, Leclerc C, Sengphommachanh K, Vuitton DA, Liance M. In vivo treatment with recombinant IL-12 protects $(57 \mathrm{BL} / 6 \mathrm{~J}$ mice against secondary alveolar echinococcosis. Parasite Immunol. 1998;20:81-91.

36. Valot B, Rognon B, Prenel A, Baraquin A, Knapp J, Anelli M, et al. Screening of antigenic vesicular fluid proteins of Echinococcus multilocularis as potential viability biomarkers to monitor drug response in alveolar echinococcosis patients. Proteomics Clin Appl. 2017;11:1700010.

\section{Publisher's Note}

Springer Nature remains neutral with regard to jurisdictional claims in published maps and institutional affiliations.

Ready to submit your research? Choose BMC and benefit from:

- fast, convenient online submission

- thorough peer review by experienced researchers in your field

- rapid publication on acceptance

- support for research data, including large and complex data types

- gold Open Access which fosters wider collaboration and increased citations

- maximum visibility for your research: over $100 \mathrm{M}$ website views per year

At $\mathrm{BMC}$, research is always in progress.

Learn more biomedcentral.com/submissions 